\title{
Epidemiological profile of patients with congenital glaucoma treated in the Hospital Regional de São José
}

\author{
Perfil epidemiológico dos pacientes com glaucoma \\ congênito atendidos no Hospital Regional de São José
}

Deyse Bianca Campos Brink¹, Marília Bastos Quirino Brasil', Günther Bernardes Brink

\begin{abstract}
Objective: To outline an epidemiological profile of patients with congenital glaucoma treated in the ophthalmology service, as well as the evolution of these patients with the treatment adopted. Methods: A longitudinal, retrospective, descriptive study was undertaken in order to evaluate 32 patients with congenital glaucoma treated in the clinic, from the first consultation in which they entered the service and who attended the clinic at least two times in the period from march 1st, 2009 to february 1st, 2011. Results: There was a predominance of female patients $(59.37 \%)$. In relation to the lateralization, both eyes were affected in $91 \%$ of the cases. Most patients $(78.12 \%)$ presented primary congenital glaucoma. Eighty-five surgeries were performed for congenital glaucoma, $63.52 \%$ of them were submitted to trabeculotomy. The intraocular pressure measured in the first and in the last consultation diminished in $85.93 \%$ of the 64 eyes, and in relation to the mean intraocular pressure there was a decrease of $82.81 \%$ in relation to the value of the first consultation. When making the comparison of the horizontal corneal diameter of the first consultation in relation to the last one, as well as of the first consultation in relation to the average of the measurements of all consultations, in $25.42 \%$ there was an increase. Conclusion: In the patients with congenital glaucoma, there was a predominance of bilateral involvement and of female patients. Most patients presented a decrease of intraocular pressure in the last consultation in relation to the first one, and in a few patients there was an increase of horizontal corneal diameter.
\end{abstract}

Keywords: Glaucoma/congenital; Glaucoma/epidemiology; Trabeculectomy; Hydrophthalmos; Intraocular pressure

\section{RESUMO}

Objetivo: Delinear um perfil epidemiológico de pacientes com glaucoma congênito atendidos no serviço de Oftalmologia do Hospital Regional de São José, bem como a evolução destes pacientes com os tratamentos empregados. Métodos: Foi realizado um estudo longitudinal, retrospectivo, descritivo que avaliou 32 pacientes com glaucoma congênito atendidos em ambulatório, desde a primeira consulta quando ingressaram no serviço e consultaram pelo menos duas vezes no período de $1^{\circ}$ de março de 2009 até $1^{o}$ de fevereiro de 2011. Resultados: Houve predominância do sexo feminino (59,37\%). Com relação à lateralidade, ambos os olhos foram acometidos em $91 \%$ dos casos. A maioria dos pacientes $(78,12 \%)$ apresentava glaucoma congênito primário. Oitenta e cinco cirurgias foram realizadas para o glaucoma congênito, destes $63,52 \%$ foram submetidos à trabeculotomia. A pressão intraocular aferida na primeira e na última consulta diminuiu em $85,93 \%$ dos 64 olhos, já em relação à pressão intraocular média houve uma diminuição de $82,81 \%$ em relação ao valor na primeira consulta. Ao realizar a comparação do diâmetro corneano horizontal da primeira consulta em relação à última, bem como da primeira consulta em relação à média das aferições de todas as consultas, em 25,42\% ocorreu aumento. Conclusão: Nos pacientes com glaucoma congênito, houve predomínio do acometimento bilateral e do sexo feminino. A maioria dos pacientes apresentou diminuição da pressão intraocular na última consulta em relação à primeira e em poucos pacientes houve um aumento do diâmetro corneano horizontal.

Descritores: Glaucoma/congênito; Glaucoma/epidemiologia; Trabeculectomia; Hidroftalmia; Pressão intraocular

${ }^{1}$ Hospital Regional de São José Dr. Homero de Miranda Gomes (HRSJ-HMG) - São José (SC), Brasil.

The authors declare no conflicts de interest

Received for publication 12/05/2013 - Accepted for publication 07/10/2013

Rev Bras Oftalmol. 2015; 74 (3): 133-7 


\section{INTRODUCTION}

$\mathbf{C}$ ongenital glaucoma is a disease with bilateral manifestation in $75 \%$ of cases ${ }^{(1,2)}$, asymmetric evolution, which reaches males more frequently ${ }^{(1)}$. Most cases are sporadic. In approximately $10 \%$ of cases it is believed that the pattern of inheritance is autosomal recessive ${ }^{(1)}$.

Congenital glaucoma can be separated into three groups ${ }^{(1,}$ 3-6). The first is composed of isolated congenital glaucoma, wherein the abnormal developedment of the angle of the anterior chamber leads to an obstruction of aqueous flow in consistent association with the development of other ocular or systemic abnormalities. The second one involves development glaucoma associated to some abnormality in which a developmental abnormality is responsible for glaucoma, but additional ocular and systemic changes are present. The third group includes glaucoma acquired during the childhood (secondary glaucoma) in which the flux obstruction mechanism is acquired by means of other events such as inflammation, rather than a change of angle development ${ }^{(1)}$.

Primary congenital glaucoma (PCG) is a rare diseasewhich has an overall incidence of 1 in every 10,000 births ${ }^{(1,5,6)}$ and can vary among populations and continents. Due to consanguinity, GCP is more frequent in isolated populations, such as in Saudi Arabia $(1: 2,500)^{(2,6)}$, among gypsies in Slovakia $(1: 1,250)^{(6)}$ and among people of Andhra Pradesh, India (1:3300) ${ }^{(6)}$.

The treatment for congenital glaucoma is essentially surgical $^{(1,2,5-12)}$. Goniotomy is the chosen procedure whenever the degree of corneal transparency allows to realize $\mathrm{it}^{(1,5,6)}$. Trabeculotomy, in turn, is indicated when the camerular vision is impaired ${ }^{(1,5,6)}$. Surgical alternatives are trabeculectomy with administration of mitomycin $\mathrm{C}$, artificial devices to drain the aqueous humor and the cyclodestructive procedures ${ }^{(1,5,13)}$.

To follow the patient with congenital glaucoma, in addition to the measurement of intraocular pressure, the serial measurement of corneal diameter $(1,2,5,7,8,14-16)$, the echobiometry ${ }^{(1,5,7,10,14)}$ and assessment of signs and symptoms should be included. The reduction of the intraocular pressure decreases corneal edema and therefore the symptoms related to it.

The present paper aims at outlining an epidemiological profile of patients with congenital glaucoma treated at the Ophthalmology service at the Regional Hospital of São José, considered a referral hospital in Santa Catarina, as well as the evolution of said patients to the treatments performed.

\section{Methods}

This was a longitudinal, retrospective, descriptive study which evaluated 32 patients diagnosed with congenital glaucoma treated at the glaucoma ambulatory of the Regional Hospital of São José (HSRJ) since the first consultation when they joined the service and who were consulted at least twice during the period from March 1, 2009 to February 1, 2011.

The data assessed were: gender, affected eye, family history, age at the last consultation, age when diagnosed with congenital glaucoma, who suspected that there was some ocular disease in the child and suggested to look for a consultation with an expert, region of origin on Santa Catarina, signs and symptoms present at the first consultation, eye fundus exam, measuring the axial ocular length by ultrasound type A, ocular and systemic associated changes and type of treatment. We also assessed the extent of the horizontal corneal diameter and the intraocular pressure at every consultation. These data were input in Microsoft Office Excel 2007 for the calculation of percentages.

Was considered, during the evaluation of the intraocular pressure and the horizontal corneal diameter, the value in the first and last consultations, as well as the average value in all consultations.

The measurement of the horizontal corneal diameter was performed with a compass, and the intraocular pressure with the Perkins tonometer.

Regarding the age of diagnosis of congenital glaucoma, patients were divided into seven different age groups: 1) 0 to 9 days; 2) 10 days to 1 month; 3 ) $>1$ month to 3 months; 4 ) $>3$ to 6 months; 5) > 6 months to 1 year; 6) $>1$ year to 3 years; 7) $>3$ years. Regarding the age at the last consultation, patients were divided into nine age groups: 1) 6 months to one year; 2) $>1$ year to 2 years; 3 ) $>2$ to 3 years; 4 ) $>3$ to 5 years; 5 ) $>5$ to 7 years; 6 ) $>7$ to 9 years; 7) $>9$ to 12 years; 8 ) $>12$ to 16 years;9) $>16$ years.

The region of origin in Santa Catarina was classified into eight regions following the geographical classification: coast, northeast, Itajaí valley, Planalto Norte, Planalto Serrano, south, midwest and west.

\section{Results}

From a total of 32 patients with congenital glaucoma, 19 were female $(59.37 \%)$ and 13 were male $(40.62 \%)$. The average age at the last consultation was 7.06 years, with its extremes ranging from 7 months to 32 years (Table 1).

Regarding the family history only $16 \%$ of patients presented other cases of congenital glaucoma in the family, and in none of the cases the parents were consanguineous. In $80 \%$ of patients whose family history was positive the diagnosis was primary congenital glaucoma.

Regarding laterality, 29 patients (91\%) had glaucoma in both eyes, and 3 ( $9 \%$ ) had unilateral glaucoma.

The municipalities in the south were reported as origin by seven patients $(22 \%)$. The group comprising the state's coast as origin accounted for six cases $(19 \%)$. Less common, the origin was reported in municipalities of Itajaí valley in two cases $(6 \%)$. None of the patients in the sample was from cities in Planalto Norte (Figure 1).

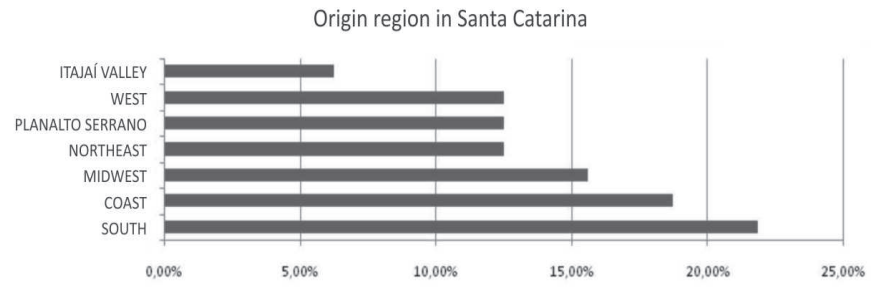

Figure 1. Distribution of 32 patients, according to the origin.

Regarding the age of diagnosis of congenital glaucoma, it was observed that the group (0 to 9 days) accounted for 10 cases $(31.25 \%)$ (Figure 2). 
Age of the patient when diagnosed with congenital glaucoma

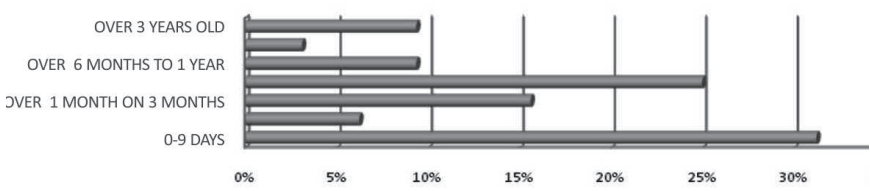

Figura 2. Distribution of the 32 patients according to the age when they were diagnosed with congenital glaucoma

The person who suspected of some ocular disease in the children and sought specialized care was the mother of these patients in $60 \%$ of cases, the pediatrician was responsible for $25 \%$ of suspicions and grandparents of $6 \%$. The symptom that prevailed in the first consultation was photophobia $(65.62 \%)$, followed by epiphora with 13 cases $(40.62 \%)$. Regarding signs in the first consultation $56.25 \%$ of the cases showed corneal opacity, and $81.25 \%$ an increase in eye size.

The majority of patients $(78.12 \%)$ had primary congenital glaucoma, $6.25 \%$ had associated ocular changes, and $15.62 \%$ systemic changes (Table 1 ).

Table 1

Distribution of the 32 patients in relation to sex, age at the last consultation and the classification of congenital glaucoma

\begin{tabular}{lcc}
\hline & Number & \% \\
\hline Sex: Female & 19 & 59.37 \\
$\quad$ Male & 13 & 40.62 \\
Age at the last consultation & & \\
$\quad 6$ months up to one year & 2 & 6 \\
$>$ 1 year to 2 years & 4 & 13 \\
> 2 to 3 years & 4 & 13 \\
$>3$ to 5 years & 6 & 19 \\
$>$ 5 to 7 years & 3 & 9 \\
$>7$ to 9 years & 3 & 9 \\
$>9$ to 12 years & 2 & 6 \\
>12 to 16 years & 5 & 16 \\
>16 years & 3 & 9 \\
Congenital glaucoma rating & & \\
Primary congenital glaucoma & 25 & 78.12 \\
Glaucoma associated with & & \\
congenital anomalies & 7 & 21.88 \\
Glaucoma acquired in childhood & 0 & 0 \\
\hline
\end{tabular}

The mean time of follow-up of patients in the glaucoma service at the HRSJ since the first consultation and who stayed at the service until the last one was 41.5 months, with its extremes ranging from 2 months to 173 months (Figure 3).

$\mathrm{O}$ exame de fundoscopia foi impossível devido à opacidade de meios, na primeira consulta, em 48,43\% dos 64 olhos avaliados.

The fundoscopy exam was impossible to be performed due to media opacity in the first consultation in $48.43 \%$ of the 64 eyes assessed.

The anteroposterior diameter (APD) in $65 \%$ of cases was higher than expected for the age (months) of the patient in relation to the values expected in the forecast line ${ }^{(1)}$, but in relation

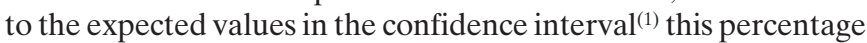

increased to $76.66 \%$. When we consider only the point value expected for the patient's age in months regardless of the normal range, in $80 \%$ APD was higher than expected (Figure 4). In 4 eyes measuring the ocular axial length by ultrasound type A was not performed (in patient 3 it was not performed in both eyes, in patients 15 and 20 in the left eye).

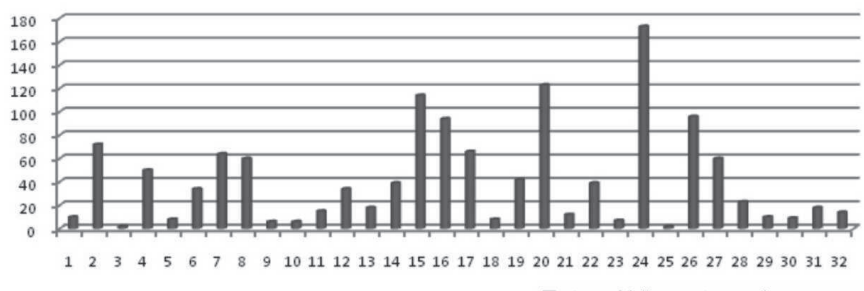

- Time of follow-up in months

Figure 3. Time of follow-up of each patient from the first consultation to the last in months

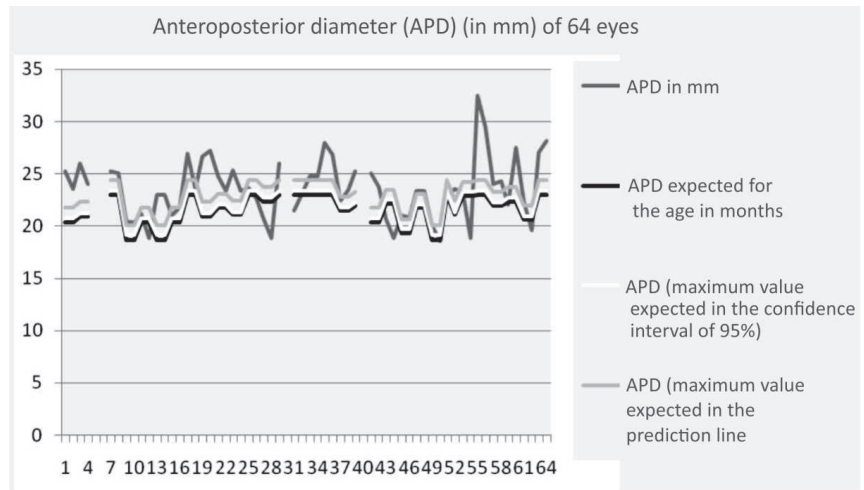

Figure 4. Distribution of 64 eyes of 32 patients who were attended at the HRSJ-HMG, according to the anteroposterior diameter (APD) (in $\mathrm{mm}$ ) of the right eye and the left eye compared to the APD expected for their age in months, with the expected value at the confidence interval of $95 \%^{(1)}$ and the expected value of the prediction line ${ }^{(1)}$.

85 surgeries for congenital glaucoma were performed at the HRSJ, from these $63.52 \%$ were trabeculotomy, $20 \%$ trabeculectomy + mitomycin C, $8.23 \%$ Molteno tube implant, $7.05 \%$ trabeculotomy associated with trabeculectomy + mitomycin C, $1.17 \%$ Ahmed valve implant. In three patients $(9.37 \%)$ surgical intervention was not necessary, as they had already been operated in another hospital and presented a stable condition (Figure 5). In the last visit $43.75 \%$ of the 64 eyes evaluated were not using eyedrops to control intraocular pressure, $20.31 \%$ were using only one eyedrops, $21.87 \%$ were using two eyedrops (Figure 6).

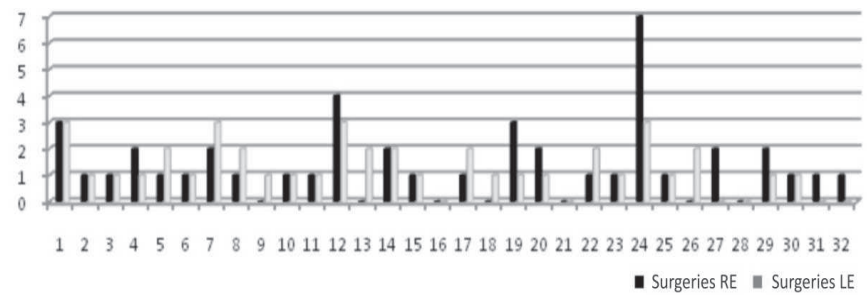

Figure 5. Distribution of 32 patients according to the number of surgeries for congenital glaucoma 


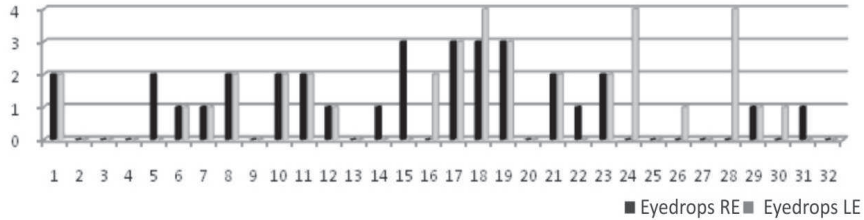

Figure 6. Distribution of 32 patients according to the number of hypotensive eyedrops in use in the last consultation

The intraocular pressure measured in the first and last consultation decreased by $85.93 \%$ of the 64 eyes, but regarding the mean intraocular pressure there was a decrease of $82.81 \%$ from the value at the first consultation. In $15.62 \%$ of the eyes the PIO value increased if we compare the measure in the first consutation and the mean of all measurements. It was observed in $10.93 \%$ of the cases when comparing only the PIO at the first and the last consultations

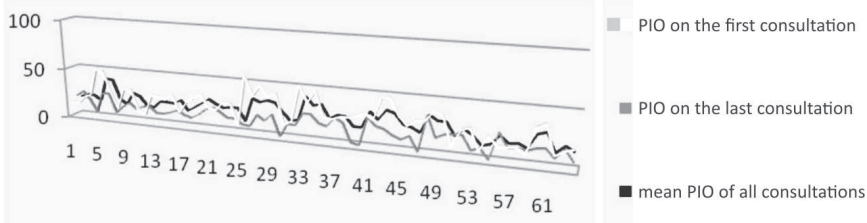

Figure 7. Distribution of 64 eyes of 32 patients according to the PIO of the right eye and the left eye during the first and the last consultations in numbers $(\mathrm{mmHg})$, and the mean intraocular pressure of all consultations.

The horizontal corneal diameter can be compared in 59 eyes, because in 5 eyes there was no adequate measurement. From these five eyes in which the corneal diameter was not measured, four had Phthisis bulbi (patients 15 and 20 in the left eye and patients 24 and 28 in the right eye), and for this reason the serial measurement was not performed. The Phthisis bulbi was diagnosed in one patient after the surgery performed athe the HRSJ, in two patients it was secondary to trauma, and one was already presenting the condition when the follow-up at the service started.

The horizontal corneal diameter in $52.54 \%$, i.e., in 31 eyes remained the same in all consultations. When we compared the horizontal corneal diameter of the first consultation against the last one and the first consultation against the mean measurement of all consultations, in $25.42 \%$ there was an increased (Figure 8 ).

The total was, therefore, 15 eyes with increased horizontal corneal diameter during the follow-up. From these in only 2 $(13.33 \%)$ the mean PIO increased in relation to the measurement of PIO in the first consultation.
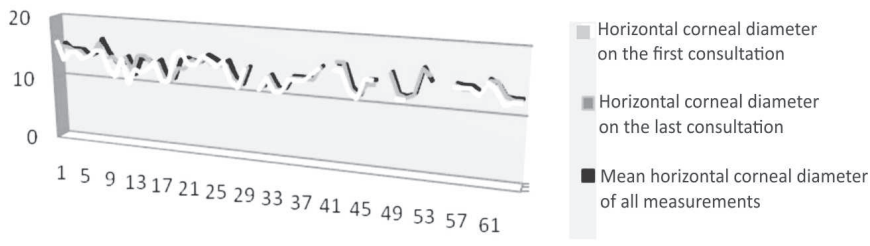

Figure 8. Distribution of 64 eyes of 32 patients according to the horizontal corneal diameter of the right eye and the left eye in the first and the last consutations in number $(\mathrm{mm})$, and the mean measurement of the horizontal corneal diameter of all consultations.

\section{Discussion}

Primary congenital glaucoma occurs in about 1 in 10,000 births $^{(1,5,6)}$. In this study, $78.12 \%$ of the patients had primary congenital glaucoma.

There was a predominance of females and bilateral occurrence in this study. The literature showed a preponderance of males ${ }^{(1,5,17)}$ and a prevalence of bilaterality in $65-80 \%$ of the cases $^{(1,2,5,17,18)}$. However, in Japan females are the most affected, with a ratio of girls to boys of $3: 2^{(6)}$. There are no available data on the epidemiology of congenital glaucoma in the Brazilian population $^{(6)}$.

The region of origin was included in the survey in order to try to delineate the epidemiology, even with limitations and limited to the patients treated at the Single Health System (SUS) in Santa Catarina. None of the patients in the sample were from cities in Planalto Norte, which has border with the state of Paraná, with the possibility of the same being referred to the neighboring state.

The evolution of congenital glaucoma is predominantly asymmetric $^{(1)}$ so the comparative exam between the eyes shall always be performed. In this study, 61 eyes had congenital glaucoma, but the follow-up was performed in the 64 eyes. Patients 27 and 31 had congenital glaucoma only in the right eye, and patient 26 only in the left eye.

Regarding the family history, $84 \%$ of patients with congenital glaucoma had no history of disease in the family. However, regardless of family history, parents of children with primary congenital glaucoma should be aware of the risk of transmitting this feature to the other children, even with this risk being small (assuming the recessive autosomal inheritance) $)^{(1,6)}$. All siblings of any child with primary congenital glaucoma should therefore be carefully analyzed to exclude this disease.

The onset of the clinical profile of the disease appears during the first year of life in more than $80 \%$ of cases, of which $25 \%$ are diagnosed in the neonatal period and $60 \%$ during the first 6 months of life ${ }^{(6,17)}$. In the study of the profile of patients with congenital glaucoma most patients were diagnosed before 10 days after birth $(31.25 \%)$, and only $21.86 \%$ of the cases were diagnosed after 6 months, i.e., as described in the literature.

Pediatricians are responsible for the diagnosis and treatment of the simplest eye diseases, as well as referral to the specialized eye examination when necessary. In this study, the pediatrician was responsible for $25 \%$ of suspicions. A survey conducted in Porto Alegre about the knowledge of pediatricians of eye disorders in children ${ }^{(19)}$ showed that $52 \%$ of them did not know that the symptom triad of congenital glaucoma is photophobia, epiphora and blepharospasm.

In glaucoma that appears after one year of age, it is difficult that there is photophobia ${ }^{(1)}$. Four patients $(12.5 \%)$ were diagnosed after 1 year of age; from these $50 \%$ had photophobia at the diagnosis.

When the glaucomatous process sets in the first 3 years of life, due to the characteristics of eye collagen fibers at this age, the size of the eyeball tends to increase ${ }^{(1)}$. In children over 3 years the previous segment shows no signs of increased dimensions, which makes it more difficult to diagnose glaucoma ${ }^{(1)}$. Three patients $(9.37 \%)$ were diagnosed after 3 years of age; from them only one had increased ocular dimensions.

The horizontal corneal diameter of a normal newborn ranges from 10 to $10.5 \mathrm{~mm}$ and reaches values from 11 to $12 \mathrm{~mm}$ at 1 year of age $\mathrm{e}^{(1)}$ and it is considered a parameter for the follow-up 
of children with congenital glaucoma ${ }^{(1,5,14,19)}$. Kiskis et al. studied 31 eyes of 17 children with primary congenital glaucoma and concluded that the corneal diameter is the most sensitive parameter $(97 \%)$ and does not require any expensive equipment ${ }^{(20)}$. At HRSJ it is the parameter used to follow up patients with congenital glaucoma along with the measurement of the intraocular pressure.

The measurement of the ocular axial length by ultrasound type $\mathrm{A}$ is an exam that aids in the diagnosis and follow-up of congenital glaucoma ${ }^{(1,5,7,10,14,17)}$. However, it is not a parameter used as a follow-up at HRSJ for all patients due to the nonavailability of the same during the exam under sedation performed in the operating room. To use the anteroposterior diameter (APD) as a preparatory means in childhood it is necessary to know the dimensions of the normal eye in this age group $^{(1)}$. In the present study, this comparison was conducted by the table presented in the reference ${ }^{(1)}$, with the correlation being performed between the APD (in $\mathrm{mm}$ ) and the age (in months) in normal eyes and in the patients studied, taking into account the mean value as well as the values found in the confidence interval of $95 \%^{(1)}$ and the values in the existing forecast line ${ }^{(1)}$.

In general the treatment of congenital glaucoma is surgical $^{(1,2,5-7,9,11-13,17,18)}$, and clinical treatment is used only as a support ${ }^{(1,5,17)}$. The first choice for clinical treatment is the eyedrops of beta-blockers and carbonic anhydrase inhibitors ${ }^{(5,17)}$, and the alpha agonist eyedrops are contraindicated (1.17). In HRSJ when there is need for associated clinical therapy there is a preference to eyedrops of beta-blockers and topic inhibitors of carbonic anhydrase.

Goniotomy is the procedure of choice in some hospitals. However, it requires the transparency of the cornea and gonioscopic lens of direct observation. In the study presented herein said procedure was not performed in any patient. The literature describes the goniotomy results as very similar to the trabeculotomy, with a success rate around $90 \%{ }^{(1,18)}$.

In the glaucoma service, trabeculotomy is the procedure adopted in patients with primary congenital glaucoma. The advantage of said procedure is that it is independent of the transparency means to be realized. On the other hand, to perform the trabeculotomy, unlike goniotomy, it is necessary to manipulate the conjunctival, causing a fibrotic scarring ${ }^{(1,17,18)}$.

One patient (24) had Phthisis bulbi after the surgery performed at the HRSJ, which is a serious complication that causes functional and aesthetic problems. This patient had already undergone 7 surgeries in the eye, which evolved into Phthisis bulbi, and the disease was difficult to be controlled despite the therapy instituted.

Children with congenital glaucoma whose eyes reach buphthalmic dimensions are exposed to blunt trauma, which can lead to rupture of the eyeball, with the ultimate evolution being atrophy of the ocular bulb ${ }^{(1)}$. Two patients developed into Phthisis bulbi after trauma.

\section{Conclusion}

Among the patients with congenital glaucoma, the prevalence was of bilateral involvement and females. Most patients showed a decrease in the intraocular pressure during the last consultation in compariosn to the first one, and few patients had an increase of the horizontal corneal diameter.

\section{ReferenCES}

1. Dias JF, Almeida HG, Prata Junior AP. Glaucoma. 4a ed. Rio de Janeiro: Cultura Médica; 2010.

2. Elder MJ. Congenital glaucoma in the West Bank and Gaza Strip. Br J Ophthalmol. 1993;77(7):413-6.

3. Dickens CJ, Hoskins Jr HD. Epidemiology and pathophysiology of congenital glaucoma. In: Ritch R, Shields MB, Krupin T. (editors). The glaucomas. 2a ed. St. Louis: Mosby; 1996.

4. Lopes Filho JG, Betinjane AJ, Carvalho CA. [Automated perimetry in patients with primary congenital glaucoma]. Arq Bras Oftalmol. 2007;70(1):37-40. Portuguese.

5. Shields MB, Allingham RR, Damji KF, Freedman S, Moroi S, Shafranov G. Shields Tratado de Glaucoma. 5a ed. Rio de Janeiro: Cultura Médica; 2008.

6. Paolera MD. Avaliação do gene CYP1B1 em pacientes com glaucoma congênito primário [tese]. São Paulo: Irmandade da Santa Casa de Misericórdia de São Paulo; 2008.

7. Alsheikheh A, Klink J, Klink T, Steffen H, Grehn F. Long-term results of surgery in childhood glaucoma. Graefes Arch Clin Exp Ophthalmol. 2007;245(2):195-203.

8. Cohen R, Almeida GV, Mandia Júnior C. [Congenital glaucoma: relationship among age, stage of evolution and surgical results]. Arq Bras Oftalmol. 1988;51(3):113-5. Portuguese.

9. Cronemberger S, Santos DV, Ramos LF, Oliveira AC, Maestrini HA, Calixto N. [Trabeculectomy with mitomycin C in patients with refractory congenital glaucoma]. Arq Bras Oftalmol. 2004;67(3):475-9. Portuguese.

10. Dietlein TS, Jacobi PC, Krieglstein GK. Prognosis of primary ab externo surgery for primary congenital glaucoma. $\mathrm{Br} \mathrm{J}$ Ophthalmol. 1999;83(3):317-22.

11. Fulcher T, Chan J, Lanigan B, Bowell R, O'Keefe M. Long-term follow up of primary trabeculectomy for infantile glaucoma. Br J Ophthalmol. 1996;80(6):499-502.

12. Passos AF, Kiefer K, Amador RC. [Results of trabeculotomytrabeculectomy in not elderly patients]. Rev Bras Oftalmol. 2009;68(4):223-30. Portuguese.

13. Chen TC, Bhatia LS, Walton DS. Ahmed valve surgery for refractory pediatric glaucoma: a report of 52 eyes. J Pediatr Ophthalmol Strabismus. 2005;42(5):274-83; quiz 304-5.

14. Betinjane AJ, Carvalho, CA. [Significance of the corneal diameter and the axial length of the eye in the evaluation of congenital glaucoma]. Rev Bras Oftalmol. 1994;53(1):35-9. Portuguese.

15. Freitas S, Domingues MF, Cotta JS, Reis FF. Glaucoma congênito: estudo retrospectivo. Acta Oftalmol. 2003;13:23-6.

16. Morin JD, Coughlin WR. Corneal changes in primary congenital glaucoma. Trans Am Ophthalmol Soc. 1980;78:123-31.

17. Shaarawy TM, Sherwood MB, Hitchings RA, Crowston JG. Glaucoma: medical diagnosis e therapy. United Kingdom: Elsevier; 2009.

18. Meirelles SH, Liporaci SD, Bloise RR, Ávila EG. Resultados em longo prazo da trabeculotomia no tratamento do glaucoma congênito primário. Rev Bras Oftalmol. 2004;63(5-6):326-33.

19. Manica MB, Côrrea ZM, Marcon IM, Telichevesky N, Loch LF. What do pediatricians know about children's eye diseases? Arq Bras Oftalmol. 2003;66(4):489-92. Portuguese.

20. Kiskis AA, Markowitz SN, Morin JD. Corneal diameter and axial length in congenital glaucoma. Can J Ophthalmol. 1985;20(3):93-7.

\section{Corresponding author:}

Deyse Bianca Campos Brink

Rua Maria Helena Kretzer, 707 - room 204 - Praia Comprida, ZIP Code: 88103-670 - São José, Santa Catarina, Brazil. 